\title{
USP8 wt Allele
}

National Cancer Institute

\section{Source}

National Cancer Institute. USP8 wt Allele. NCI Thesaurus. Code C50379.

Human USP8 wild-type allele is located in the vicinity of $15 q 21.2$ and is approximately 75

$\mathrm{kb}$ in length. This allele, which encodes ubiquitin carboxyl-terminal hydrolase 8 protein, plays a role in cell proliferation and the regulation of protein degradation. 